\title{
Processing of Forming Cutting Tools IN CAD/CAM
}

\author{
Chladil J.
}

Abstract: Generally machining of any material has to be processed considering always a tool wear. Machining of wood based shaped profiles requires solving of cutting tool geometry which enables minimal tool wear in cutting processes. The major problem can be met in place where cutting tool goes out of contact with material being cut. This problem is more significant at processes where concave cutting tools are used. Profiling of such cutting tools is then more easily solved with the use of a CAD/CAM system where any result is instantly verified. Master piece is very often used for processing of forming cutting tools.

Key words: cutting tool, wear, CAD/CAM, tool geometry
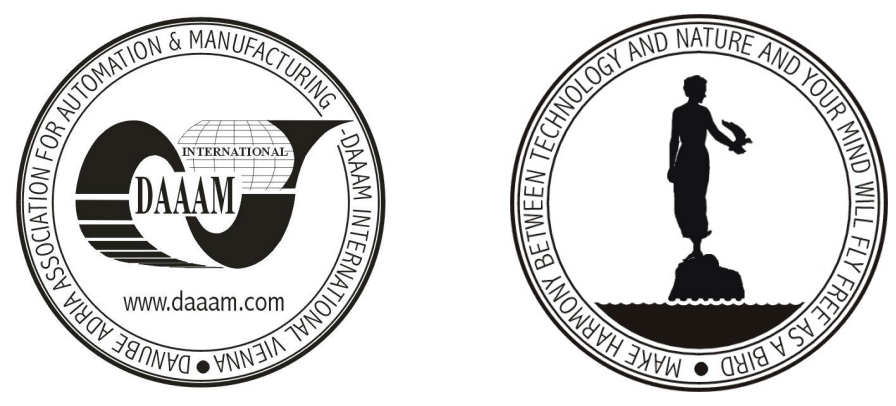

Authors' data: Doc. Ing. Chladil J.[osef], CSc., Institute of Furniture, Design and Habitat; Faculty of Forestry and Wood Technology; Mendel University of Agriculture and Forestry in Brno, chladil@mendelu.cz

This Publication has to be referred as: Chladil, J. (2006). Processing of Forming Cutting Tools in CAD/CAM, Chapter 15 in DAAAM International Scientific Book 2006, B. Katalinic (Ed.), Published by DAAAM International, ISBN 3-901509-47-X, ISSN 1726-9687, Vienna, Austria

DOI: 10.2507/daaam.scibook.2006.15 